\title{
The 1980s: D-AP5, LTP and a Decade of NMDA Receptor Discoveries
}

\author{
D. Lodge ${ }^{1} \cdot$ J. C. Watkins ${ }^{1} \cdot$ Z. A. Bortolotto ${ }^{1}$ - D. E. Jane ${ }^{1} \cdot$ A. Volianskis ${ }^{2,3}$ (])
}

Received: 26 June 2018 / Revised: 12 September 2018 / Accepted: 17 September 2018 / Published online: 4 October 2018 (c) The Author(s) 2018

\begin{abstract}
In the 1960s and 70s, biochemical and pharmacological evidence was pointing toward glutamate as a synaptic transmitter at a number of distinct receptor classes, known as NMDA and non-NMDA receptors. The field, however, lacked a potent and highly selective antagonist to block these putative postsynaptic receptors. So, the discoveries in the early 1980s of D-AP5 as a selective NMDA receptor antagonist and of its ability to block synaptic events and plasticity were a major breakthrough leading to an explosion of knowledge about this receptor subtype. During the next 10 years, the role of NMDA receptors was established in synaptic transmission, long-term potentiation, learning and memory, epilepsy, pain, among others. Hints at pharmacological heterogeneity among NMDA receptors were followed by the cloning of separate subunits. The purpose of this review is to recognize the important contributions made in the 1980s by Graham L. Collingridge and other key scientists to the advances in our understanding of the functions of NMDA receptors throughout the central nervous system.
\end{abstract}

Keywords Long-term potentiation (LTP) $\cdot$ NMDA $\cdot$ NMDA receptors $\cdot$ APV $\cdot$ D-AP5 $\cdot$ Synaptic plasticity

\section{Introduction}

The 1980s proved to be a decade where $N$-methyl-D-aspartate (NMDA) receptor-mediated neurotransmission became firmly established. Perhaps this is epitomized by the 1983 paper published by Graham Collingridge and colleagues in the Journal of Physiology that changed our understanding of neuronal plasticity and, more widely, of the functional role of NMDA receptors in the central nervous system (CNS) [1]. With Steven Kehl and Hugh McLennan, they showed that a new selective NMDA receptor antagonist, 2-amino5-phosphonovalerate (APV), inhibited the induction of long-term potentiation (LTP) of the synaptic input to CA1 neurones in hippocampal slices (Fig. 1a). Although cautious

Special issue: In honor of Graham Collingridge

A. Volianskis

a.volianskis@bristol.ac.uk; a.volianskis@qmul.ac.uk

1 Centre for Synaptic Plasticity, School of Physiology, Pharmacology and Neuroscience, University of Bristol, Bristol, UK

2 School of Clinical Sciences, University of Bristol, Bristol, UK

3 Centre for Neuroscience and Trauma, Blizard Institute, Barts and The London School of Medicine and Dentistry, Queen Mary University of London, London, UK at the time, stating that 'NMA receptors...may play a role in synaptic plasticity', this observation, and the use of this new pharmacological tool are at the core of the now established role of NMDA receptors in excitatory neurotransmission, in many forms of synaptic plasticity and hence in learning and memory. In this brief review, we will consider what led up to this important discovery, what other related events surrounded it, and what directly followed from these studies with APV in the 1980s.

APV is now more commonly known as 2-amino-5-phosphonopentanoate (AP5). Although some studies state that either the racemic mixture, D,L-AP5, or the single active isomer, D-AP5, was used, it is unclear from some reports, however, which chemical entity was used. Thus, for simplicity and because D-AP5 is the active moiety within the racemate, D-AP5 has been used throughout the main body of this review.

\section{Background to 1980 Discoveries}

In 1949, Hebb had proposed that changes in synaptic strengthening underlying learning required coincident preand post-synaptic activity [2] and, by the end of the 1960s, short lasting forms of synaptic plasticity were described in invertebrates and in the spinal cord. In their seminal review 

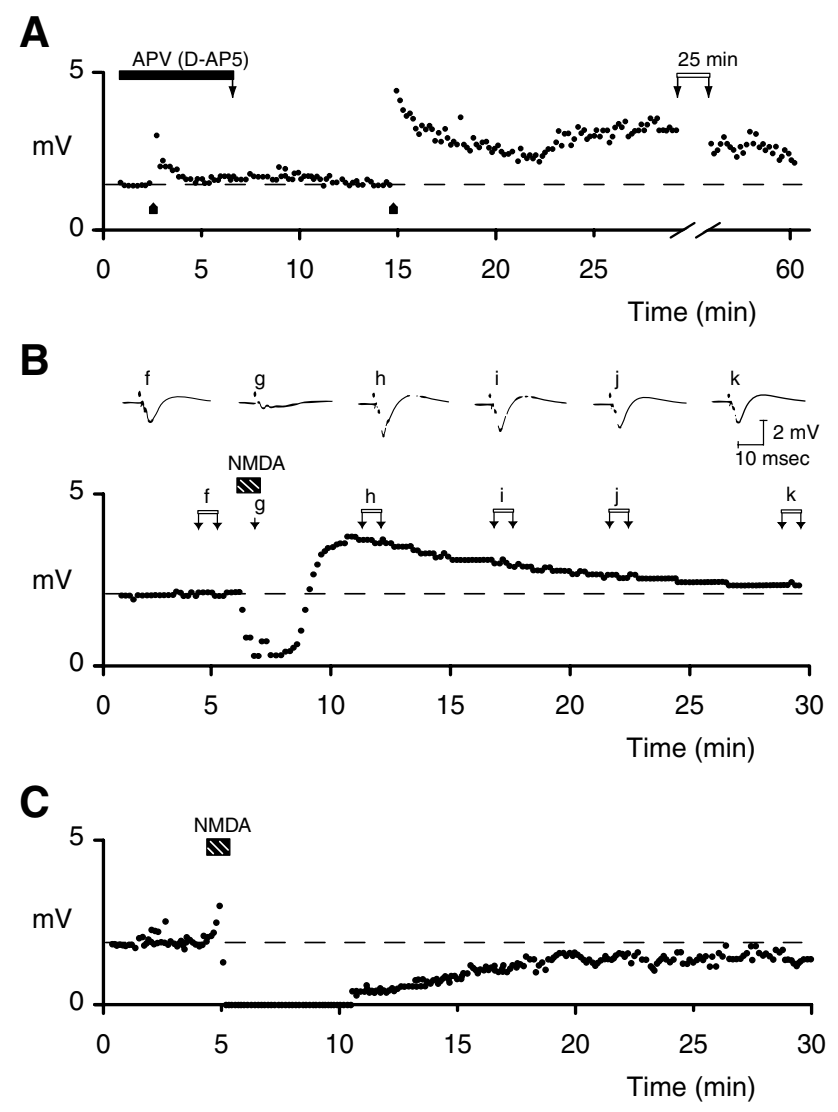

Fig. 1 D-AP5, NMDA and NMDA receptor-dependent synaptic plasticity in 1983. a Iontophoretic application of D-AP5 blocks induction of LTP, which can be readily induced after washout of the antagonist [1]. b Brief iontophoretic application of NMDA leads to a transient enhancement of field potential amplitude, which declines to baseline over time [1]. c Longer, bath application, of NMDA leads to a permanent depression of synaptic transmission [49]

of 1968, Kandel and Spencer stated that 'In contrast to the extensive data on spinal synapses, data on cortical synaptic plasticity are meager and, specifically, post-tetanic potentiation (PTP) has not yet been studied in detail comparable to that in the cord. This is unfortunate, since the complex morphology of cortical synapses may indicate a capability for unusual plastic alteration.' Indeed, although long lasting depression [3] and facilitation [4] were already observed in hippocampal synapses there were very few other accounts of synaptic plasticity in the mammalian brain [5]. The phenomenon of long-term potentiation (LTP) was first detailed by Bliss and Lomo [6] in the dentate gyrus in vivo. Soon, however, hippocampal slices [7] became the preferred preparation for studying LTP [8-10]. LTP was shown to require cooperativity between strong afferent input from many fibres and a resulting strong depolarization of the postsynaptic neurone $[11,12]$. Such potentiation was input specific so that other afferent inputs were unaffected [9] or reduced, i.e. heterosynaptic depression [13]. By contrast, a low rate of stimulation could lead to a long-term depression of all inputs [12]. The nature of the chemical transmitters involved in such processes was largely conjectural.

In the late 1970s, the concept emerged of different subtypes of glutamate receptor that mediate synaptic excitation in the central nervous system [14, 15]. Initial observations with several natural and recently synthesized acidic amino acids indicated that that $N$-methyl-D-aspartate (NMDA) was a considerably more potent excitant of central neurones than L-glutamate and L-aspartate [16, 17]. An early indication that there might be subtypes of receptors for these acidic acids was the finding that the ratios of potency between D,L-homocysteate or L-aspartate and L-glutamate, and later between NMDA and kainate, varied between different neuronal populations [18-20]. These findings were part of the developing concept of subtypes of glutamate receptors. Studies with other structurally constrained glutamate analogues from natural resources, such as kainic, domoic and quisqualic acids, suggested potential diversity of receptors mediating synaptic excitation. This diversity was supported by the observation that $\mathrm{Mg}^{2+}$ reduced the effectiveness of NMDA to a greater extent than most other glutamate analogues [21]. Further development of this concept required discovery of suitable antagonists. Longer chain analogues of glutamate, namely $\alpha$-amino-adipic and -suberic and diaminopimelic acids, were weak, selective antagonists of NMDA-induced excitation rather than that induced by quisqualate, kainate and $\alpha$-amino-3-hydroxy-5-methyl-4-isoxazolepropionic acid (AMPA) and reduced some synaptic events [22-27]. Thus the concept of NMDA and non-NMDA (later to be known as AMPA and kainate) receptors became accepted [28].

By the mid-1970 s, there were a number of papers reporting the presence, uptake and calcium-dependent release of L-glutamate and/or L-aspartate, which provided powerful evidence toward a transmitter role for these acidic amino acids [29] but the lack of selective, potent and established receptor antagonists slowed further progress in this field.

\section{D-AP5, NMDA and LTP}

Hence, the description of 2-amino-phosphonovaleric acid [30] as a potent and selective NMDA receptor antagonist at synapses on spinal neurones was the breakthrough needed to allow a thorough investigation of the physiological role of NMDA receptors.

Collingridge, being a Bristol graduate with Jeff Watkins, a PhD student with John Davies and a postdoc with Hugh McLennan, was in a good position to examine the effects of this new pharmacological tool on hippocampal slices in vitro, a preparation being used for detailed electrophysiology. Thus, Collingridge and collaborators first demonstrated that D-AP5, a gift from Jeff Watkins, was a more potent and selective NMDA receptor antagonist than previously used 
compounds, the activity lying mainly in the D-isomer [31]. With his co-authors, he then went on to show that D-AP5 reduced the synaptic potentiation in the CA1 region that followed high frequency stimulation of the Schaffer collateral input (Fig. 1a) with minimal effect on synaptic potentials at low stimulation frequencies [1]. Thus, the role of NMDA receptors in the initiation of LTP following high frequency stimulation was established in this highly quoted paper (1830 citations; Web of Science; September 2018).

This basic observation, in hippocampal slices, of the role of NMDA receptors in synaptic plasticity was rapidly seized upon and replicated by other major researchers in LTP using different paradigms but with a common D-AP5-sensitive theme: Schaffer collateral/commissural pathways to CA1 [32-35], perforant pathway to dentate gyrus in vivo [36, 37]. However, LTP at some hippocampal synapses appeared not to be mediated by NMDA receptors. For example, only the commissural, and not the mossy fibre, input to CA3 was sensitive to D-AP5 [38].

The use of D-AP5 allowed the role of NMDA receptors in LTP to be extended to rat visual cortical slices, although in this tissue GABAergic inhibition appears to play a more important modulating role than in the hippocampus [39]. In parallel, Wolf Singer's group showed that, at a critical period of development in the kitten visual cortex, D-AP5 also prevented the normal developmental process of activity-dependent modifications, which results in orientation selectivity of neurones in the visual cortex [40, 41]. NMDA receptor antagonists prevent both the loss of inappropriate synaptic connections and the strengthening of correct connections. Another form of learning during development mediated by NMDA receptors is imprinting in day-old chicks, a phenomenon in which both the learning itself and the subsequent increase in glutamate binding are sensitive to D-AP5 [42, 43].

Concurrent with these observations in mammals, the development of a retinotopic map in the tectum of frogs and goldfish was also reported to be impaired by D-AP5 [44-46]. Part of this re-wiring may require the growth of neurites and dendrites as well as cell survival processes that are also NMDA receptor-dependent $[47,48]$. Interestingly both the ability to induce cortical LTP and the density of NMDA receptors appeared to peak during this critical period for development of cortical connections, stressing the importance of NMDA receptors in this form of plasticity [49].

\section{Is NMDA Receptor Activation Sufficient for Inducing LTP?}

The discovery that D-AP5 blocked induction of LTP suggested that application of NMDA alone should be sufficient to induce plasticity. As shown in the original paper, brief exposure to NMDA results only in a transient enhancement of field potentials (Fig. 1b, [1]). In contrast, a longer application of NMDA (Fig. 1c, [50]) or glutamate [50] resulted in a depression of synaptic transmission, later recognized as NMDA receptor-dependent chemical LTD [51]. Similarly, low frequency afferent stimulation, besides limiting the induction of LTP [52], can also induce a long-term depression of synaptic transmission [12], shown in the 1990s to be D-AP5-sensitive [53, 54].

The transient enhancement of the amplitude of the field potentials, seen following NMDA application (Fig. 1b), seemed similar to the initial decremental phase of LTP (Fig. 1a), termed short-term potentiation (STP); STP, just like LTP, was D-AP5-sensitive raising the question whether STP was essential to the establishment of LTP or whether it was a mechanistically distinct parallel event $[1,55,56]$. Eventually it was shown that NMDA receptors of different subunit composition mediate induction of STP versus LTP [57] and that NMDA-induced enhancement of the field potential amplitude is distinct from STP, which is associated with a change in slope of field responses [58]. Gary Lynch's group, did, however, show that successful induction of chemical LTP could be achieved when application of NMDA was followed by a brief application of D-AP5 [59], the antagonist possibly preventing the longer activation of NMDA receptors required for the induction of LTD, thus revealing the chemical LTP.

\section{Why NMDA Receptors for LTP?}

Understanding why NMDA receptors play a unique role in synaptic potentiation depended on two key observations.

The first relates to the explanation of (i) the strange current-voltage curve of the NMDA receptor [60] and (ii) why $\mathrm{Mg}^{2+}$ ions inhibit responses to bath application of NMDA [21]. The discovery was that $\mathrm{Mg}^{2+}$ ions produce a voltage-dependent brake on channel conductance particularly at hyperpolarised membrane potentials [61, 62]. The Schaffer collaterals release glutamate onto both NMDA and AMPA receptors, the latter dominating the synaptic potential because of the $\mathrm{Mg}^{2+}$ block of the NMDA receptor. Removal of $\mathrm{Mg}^{2+}$ ions uncovered a slow NMDA component of the EPSP [63]. The NMDA receptor component also rises more slowly than the AMPA receptor component, which decays quickly not giving sufficient time for the $\mathrm{Mg}^{2+}$ block to be fully removed. The depolarisation resulting from AMPA receptor activation is not an absolute requirement: with AMPA receptors blocked, a slow synaptic depolarisation mediated by NMDA receptors is uncovered [64-67]. Thus the depolarization that follows temporal (or spatial) summation during high frequency stimulation of excitatory synaptic inputs is required to relieve the $\mathrm{Mg}^{2+}$ ion block, which immediately increases the conductance of the NMDA receptor-coupled channel $[68,69]$. This slow NMDA 
receptor component can be observed during high frequency stimulation beneath the AMPA receptor-mediated synaptic potentials [70].

The second key observation is that NMDA receptors are readily permeable to calcium when the voltage-dependent $\mathrm{Mg}^{2+}$ ion block is relieved [71]. The resultant increase in intracellular calcium, which can be visualised in dendritic spines receiving NMDA receptor activation [72] is the main driving force for plasticity in LTP induction protocols [73, 74]. Calcium activates a complex array of secondary intracellular events, including up-regulation of AMPA receptors at the potentiated synapse [75-78] and activation of protein kinases [79-82], that act as molecular switches [83, 84] and that also regulate protein synthesis dependence of the late phases of LTP [85, 86]. Much of this, including recruitment of glutamate receptors to dendritic spines, was debated early [87, 88] and detailed in subsequent decades [89-91]. Nevertheless, although the field was in general agreement about the central role of NMDA receptors in initiating LTP, there was little consensus about the mechanisms of LTP expression, which could be mediated by pre-synaptic and post-synaptic mechanisms alike [92]. The differences in the outcome of various NMDA receptor activation protocols depends among others on the extent to which different intracellular messaging systems are engaged and the type of synaptic plasticity that is induced or maintained [93, 94].

A further factor to consider is the role of inhibitory synapses, which are recruited when afferent pathways are stimulated with a tetanic pattern, including Schaffer collateralcommissural fibres into CA1. GABAergic hyperpolarisation helps maintain the $\mathrm{Mg}^{2+}$ brake on the NMDA receptor conductance. Blocking GABA-A receptor-mediated inhibition reveals the NMDA receptor component at low and high frequencies of stimulation [68, 95] and facilitates LTP [96, 97]. During high frequency bursts, postsynaptic GABAergic inhibition declines and hence allows calcium flux through NMDA receptor channels [98]. The more natural theta stimulation allows very short trains of stimuli to induce LTP [99, $100]$ in which postsynaptic GABAergic inhibition is less prominent, itself being regulated by presynaptic GABA-B receptor-mediated inhibition [93, 94].

Temporal summation or frequency dependence of the recruitment of NMDA receptors, the resultant dendritic depolarization and calcium entry are the driving forces of LTP [70, 101]. Thus, NMDA receptors function as coincidence detectors that sense synchronised pre- and post-synaptic activity and uniquely allow for the Hebbian principle of cooperativity, between strong afferent input and marked postsynaptic depolarization, which is required for synaptic strengthening [68, 69, 102, 103]. This aspect of cooperativity can be side-stepped, as described above, by a small postsynaptic depolarization, reducing extracellular $\mathrm{Mg}^{2+}$ ion concentration or reducing post- or pre-synaptic GABAergic inhibition, when low frequency stimulation can induce LTP [68, 103-105].

\section{Ubiquity of NMDA Receptors}

As is apparent from the above sections, NMDA receptors are not unique to the Schaffer collateral synapse on the CA1 hippocampal pyramidal neurones. The development of DAP5, as a potent and selective NMDA receptor antagonist, allowed the role of NMDA receptors to be more widely investigated.

Indeed reports of a transmitter role for NMDA receptors onto spinal neurones in vivo using weaker NMDA receptor antagonists (see above) preceded the hippocampal papers. Interestingly using D-AP5, a single stimulus of peripheral afferents, unlike the initial reports in the hippocampus [1], could evoke NMDA receptor-mediated synaptic potentials in spinal neurones $[30,106]$. The causal features of this difference are likely to be the more depolarized state in vivo and the temporal and spatial summation that occurs following stimulation of a mixed population of primary afferents and internuncial neurones in the spinal cord experiments. Frequency-dependent depolarization and potentiation, sensitive to NMDA receptor antagonists such as D-AP5, are also seen in these spinal pathways $[107,108]$.

Throughout the 1980s, D-AP5 was used to demonstrate a transmitter role for NMDA receptors throughout the brain; substantia nigra [109], dentate gyrus [110], interpeduncular nucleus [111], cerebellar Purkinje cells [112], neocortical neurones [113], red nucleus [114] and ventro-basal thalamus [115] as well as in sympathetic ganglia [116].

Most of the above studies were performed on rats or other mammals, although NMDA receptor-mediated D-AP5-sensitive synaptic excitation was earlier demonstrated in the spinal cord of amphibians [117-119] and of fish [120,121] and in the retina of fish $[122,123]$. Interestingly, superfusion of the exposed spinal cord with NMDA is able to initiate fictive locomotion in both frogs and lampreys, a pattern blocked by D-AP5 $[118,120]$.

Thus it became apparent in the 1980s that NMDA receptors were important mediators of synaptic transmission throughout the central nervous system of vertebrates, although the question of the natural transmitter was still unanswered. L-Aspartate and L-glutamate, although mimicking the effects of NMDA, were considerably less potent than NMDA itself in most assays, despite biochemical evidence supporting a transmitter role for these two amino acids [29]. Two key observations in the 1980s supported L-glutamate as the candidate. Firstly, in the absence of amino acid transport processes, L-glutamate became tenfold more potent than NMDA on dissociated neurones [124]. Secondly, in binding studies, L-glutamate was tenfold more potent than L-aspartate as an inhibitor of radioactive D-AP5 binding to 
NMDA receptors in rat brain membranes [125] and had an indistinguishable autoradiographic distribution to D-AP5 in rat brain [126].

\section{Epilepsy}

Epilepsy results from changes in brain circuitry excitability that lead to bursts of cortical activity arising spontaneously or from otherwise subthreshold events. A prime example of such epileptogenesis is the phenomenon of kindling, a form of plasticity following repetitive brain stimulation that leads to epilepsy-like convulsions. Kindling has features in common with LTP $[127,128]$. In particular, D-AP5 prevents the induction of the epileptiform activity, but also reduces the resultant seizure-like discharges, following kindling protocols [129, 130].

However, the first real evidence of the role of NMDA receptors in epilepsy came from in vivo studies in Harry Bradford's and Brian Meldrum's laboratories. They showed that local administration of D-AP5 reduced seizures resulting from a cobalt-induced lesion [131] and both sound-induced seizures in DBA-2 mice and pentylenetetrazol-induced seizures in Swiss mice [132] as well as photic stimulated epilepsy in primates [133]. The striking correlation in potency between NMDA receptor antagonism in vitro and that against seizures of three competitive NMDA receptor antagonists substantiated the importance of NMDA receptors as anticonvulsants [132].

This was followed by many publications showing that both induction and maintenance of many forms of epileptiform activity in hippocampal slices [95, 134-137] and in cortical slices $[138,139]$ could be prevented by D-AP5. This included the blocking of ex vivo bursting epileptogenic foci in kainate-lesioned rat hippocampi [140] and in surgically removed human neocortex [141]. The bursting pattern of layer 4/5 neurones during slow wave sleep was also blocked by local ejection of D-AP5 [142].

The role of NMDA receptors in, and the use of NMDA receptor antagonists for, various forms of epilepsy is still a subject of therapeutic interest.

\section{Pain}

Another therapeutically important aspect of plasticity is the development of neuropathic and other chronic pain conditions, for example phantom limb pain. Such maladapted plasticity may lead to hyperalgesia and allodynia, two symptoms that indicate nociceptive pathways have been abnormally strengthened or new ones formed.

Because, as mentioned earlier, the polysynaptic excitation of spinal neurones following afferent stimulation of hind limb nerves is mediated by NMDA receptors [22-24, $30,106]$, it was not surprising that NMDA and D-AP5, respectively, induced and reduced nociceptive responses following local application to the spinal cord [143-145].

Concerning plasticity, the phenomenon of 'wind-up' whereby repetitive nociceptor fibre stimulation leads to a potentiated response of spinal neurones [146] is thought to underlie central sensitization leading to hyperalgesia. This form of plasticity is prevented by D-AP5 following local spinal application in vivo [107] and following bath application in vitro [147]. Unilateral foot paw tissue damage may result in secondary hyperalgesia in the contralateral limb, which can be prevented by spinal administration of D-AP5 [148]. Nevertheless weak bioavailability of D-AP5 has limited its use in vivo for researching the role of NMDA receptors in various pain states.

\section{D-AP5 and Memory}

Because LTP is thought to be one of the mechanisms underlying learning and memory, it was not surprising that the effects of D-AP5 were assessed in learning paradigms rapidly following the description of its block of LTP [1]. Parallels had already been drawn between the rate of decline of LTP and of loss of memory in older rats (reviewed in [149]).

Because of the low bioavailability of competitive NMDA receptor antagonists in general, D-AP5 was injected into the cerebral ventricles (i.c.v.) in the early experiments of Richard Morris and collaborators. Treated and untreated rats, placed in a large pool of opaque water, were compared for their ability to learn the position of a hidden escape platform over a 5 day period, a task now known as the Morris Water Maze. The results were highly significant in that the D-AP5 treated animals took much longer to learn the location of the platform, spending much less time than the controls in the correct quadrant of the pool [36]. D-AP5-treated animals did not show deficits in a visual discrimination test suggesting a role for NMDA receptors specifically in spatial learning, which is thought to be a hippocampus-based phenomenon. By changing the time of administration of D-AP5, they were able to show that, in parallel with LTP, NMDA receptors were required for the acquisition or encoding of memory but not for its storage or retrieval [150], see also [151].

Similarly, i.c.v. D-AP5 disrupted acquisition of short term memory (radial maze) and attenuated retention of long term memory (passive avoidance) provided the drug was injected before the learning phase [152] and prior administration of D-AP5 could result in memory decline in an operant learning paradigm [153]. Acquisition of odour discrimination was also prevented by D-AP5 but previously learned memories were not disrupted [154]. These data extended the concept of an NMDA receptor-mediated LTP-like plasticity requirement from the hippocampal-based spatial domain to other forms of learning and memory. 


\section{Neurotoxicity and Neuroprotection}

In contrast to its positive role in neuroplasticity, excess NMDA receptor activation can lead to D-AP5-sensitive neurodegeneration $[155,156]$. This sensitivity to NMDAinduced neurotoxicity varies between populations of neurones, a finding likely related to the differences in NMDA receptor expression and/or calcium buffering [157]. Release of glutamate following excessive and/or prolonged stimulation of neuronal pathways can also result in D-AP5-sensitive degeneration of targetted neurones [158] similar to that following epileptiform activity in hippocampal slices [159, 160].

Brain ischaemia and hypoglycaemia lead to high extracellular levels of glutamate [161-163]. Although competitive NMDA receptor antagonists have been shown to be effective in reducing neuronal cell loss following temporary carotid artery occlusion [164] and hypoglycaemia [165], the hope for them as clinical agents [166] has not yet been realized.

\section{Beyond D-AP5: Medicinal Chemistry Around the NMDA Receptor}

Although the synthesis of NMDA was first reported in 1962 [167], it wasn't until much later that chemists developed more potent agonists by conformational restriction of either aspartate or glutamate (reviewed in [174]). Such agonists include $\alpha$-tetrazolylglycine [168], the cyclobutane transACBD $[169,170]$ and the cyclopropanes D-CCG-II and L-CCG-IV [171-173].

Following the success of D-AP5 in forwarding our understanding of the role of NMDA receptors, medicinal chemists in academia and industry continued to develop new compounds in order to increase potency and/or bioavailability (reviewed in [174]). Increasing the affinity of D-AP5 was achieved by conformational restriction for example by incorporating a double bond into the side chain (e.g. CGP 37849 and its $\alpha$-carboxyethyl ester CGP 39551, [175]), or incorporating the $\alpha$-amino group and some of the side chain into a piperidine ring (e.g. CGS 19755, [176]). Like D-AP5, D-AP7, a longer chain analogue, was also found to be a competitive NMDA receptor antagonist and blocked LTP whereas D-AP4, D-AP6 and D-AP8 were essentially inactive $[32,177,178]$. Conformational restriction of D-AP7 led to the development of high affinity antagonists such as the piperazine derivatives D-CPP $[179,180]$ and D-CPPene [181], the decahydroisoquinoline LY274614 [182] and the phenylalanine SDZ EAB515 [183].

Several of these high affinity NMDA receptor antagonists were radiolabelled (e.g. [ $\left.{ }^{3} \mathrm{H}\right] \mathrm{AP} 5[125],\left[{ }^{3} \mathrm{H}\right] \mathrm{CPP}$ [184], $\left[{ }^{3} \mathrm{H}\right] \mathrm{CGS} 19755$ [185] and $\left[{ }^{3} \mathrm{H}\right] \mathrm{CGP} 39653$ [186]). They were used in binding assays and alongside $\left[{ }^{3} \mathrm{H}\right]$ glutamate [187, 188] and $\left[{ }^{3} \mathrm{H}\right] \mathrm{MK}-801$ [189] (a high affinity channel blocker) in autoradiography, to study the distribution of native NMDA receptors throughout different brain regions.

High affinity NMDA receptor antagonists were used in animal models of CNS disorders and were found to be anticonvulsant in models of epilepsy, neuroprotective in models of cerebral ischaemia and to be effective in models of chronic pain. Some, such as D-CPPene, also were taken into clinical trials for prevention of brain damage following stroke or head injury and for treatment resistant forms of epilepsy. Positive outcomes from such clinical trials, e.g. with D-CPPene and CGS19755, have been prevented by the occurrence of side effects, particularly of a psychogenic nature $[190,191]$.

\section{Coincidental but Related Pharmacological Discoveries of the 1980s}

Interestingly, Collingridge and collaborators were not the only group studying LTP pharmacologically in 1983 . Patrice Guyenet's laboratory was independently showing that the effects of phencyclidine, ketamine and sigma opiates blocked the long term potentiation of the population spike in CA1 region of the hippocampal slices [192, 193]. Equally independent was the observation that phencyclidine, ketamine and sigma opiates were selective NMDA receptor antagonists on spinal neurones in vivo [194-196]. Thus, these two independent groups coincidentally provided extra support for the role of NMDA receptors in LTP [1].

Unlike competitive NMDA receptor antagonists, ketamine blocks within the receptor-coupled channel [197], pharmacologically mimicking the voltage-dependent block of $\mathrm{Mg}^{2+}$ ions but with slower kinetics. Although there are concerns related to the specificity of ketamine and phencyclidine as NMDA receptor antagonists, particularly at higher concentrations [198], its rapid CNS bioavailability and reversibility following systemic administration makes low doses of ketamine particularly useful for studying the effects of NMDA receptors in vivo.

By the 1980s, many of the pharmacological and clinical properties of ketamine were already established in the absence of knowledge of it as an NMDA receptor antagonist. Developed as an anaesthetic, it was known for its good analgesia and its safety but with recognized emergence phenomena including hallucinations [199]. In the 1980s striking similarities between the actions of ketamine and D-AP5 emerged. For example, ketamine's effect on polysynaptic responses of spinal neurones [194, 195], on hippocampal LTP [192], on spinal 'wind-up' [108], on cortical synaptic transmission [200], on cortical epileptiform activity [201], on sound-induced seizures [202] and on ocular dominance in the visual cortex [203] echoed the effects of D-AP5 cited above. 
Fig. 2 Trends in pharmacological sciences: Special Report 1991. Cover page: This supplement was a compilation of the articles published each month during 1990 on the theme: "The Pharmacology of Excitatory Amino Acids" edited by David Lodge, and Graham L. Collingridge with Alison Abbott of Elsevier. The supplement was sponsored by Leslie L. Iversen of Merck \& Sharp and Dohme Research Laboratories. The Glutamate Tree of Life is represented in the "Cover design by Nigel Hynes, based on an original idea of David Lodge"

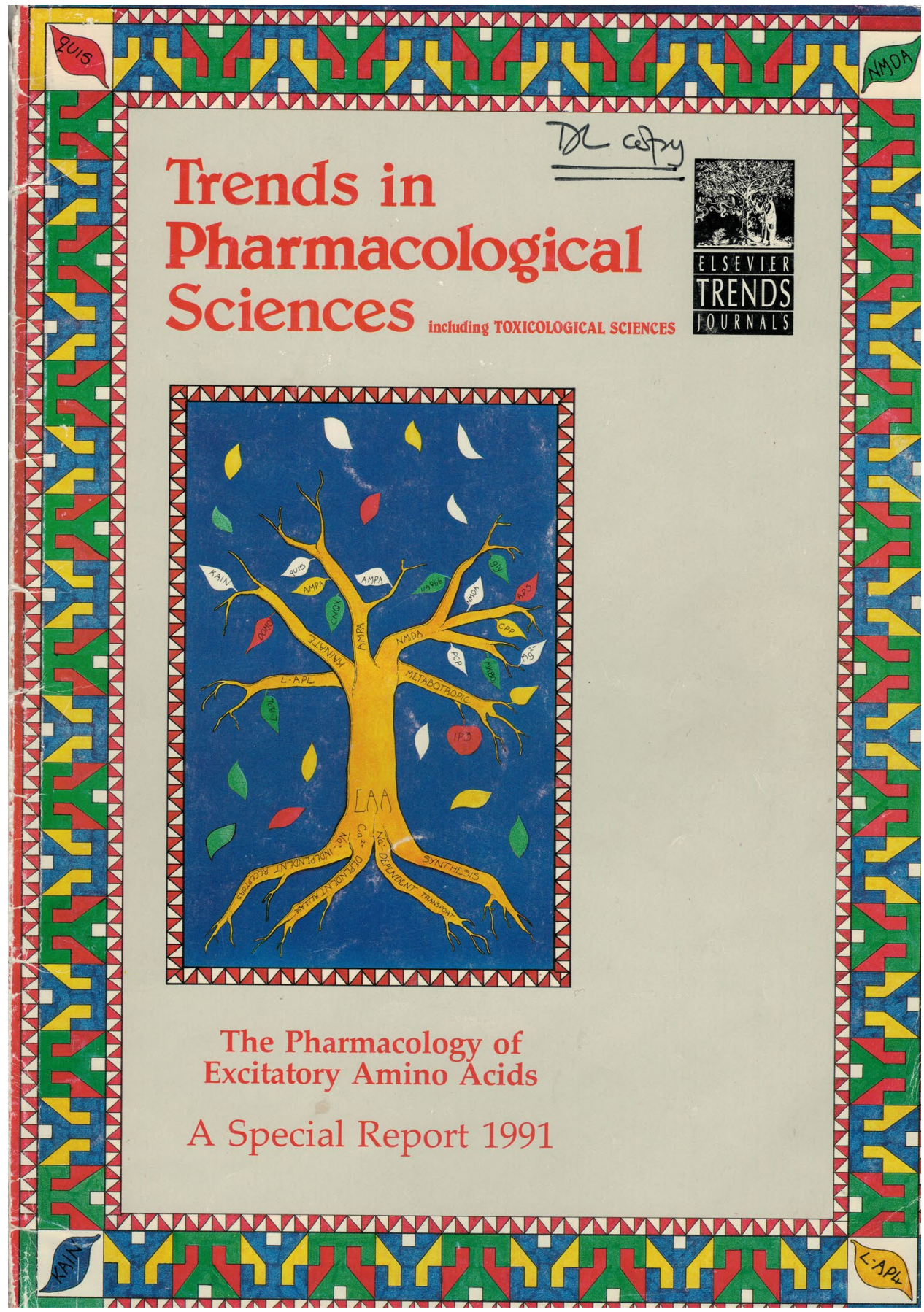

It is beyond the scope of this review to describe all the

Another major aspect of the NMDA receptor's pharmacology was discovered in the 1980s. Philippe Ascher's group showed that glycine, or a glycine-like substance such as D-serine, was a required co-agonist for NMDA receptor activation [204]. This glycine-site was not sensitive to the traditional inhibitory antagonist, strychnine. Instead, compounds such as HA-966 and 7-chlorokynurenate were shown to be NMDA receptor antagonists acting via this glycine site (for example [205-208]). contributions that using ketamine and other non-competitive NMDA antagonists including glycine-site antagonists have made to our understanding of the importance of NMDA receptors. Some of this literature, concerning the effects of ketamine in synaptic plasticity, neuroprotection, epilepsy, pain and behaviour, is cited in previous reviews [198, 209]. 


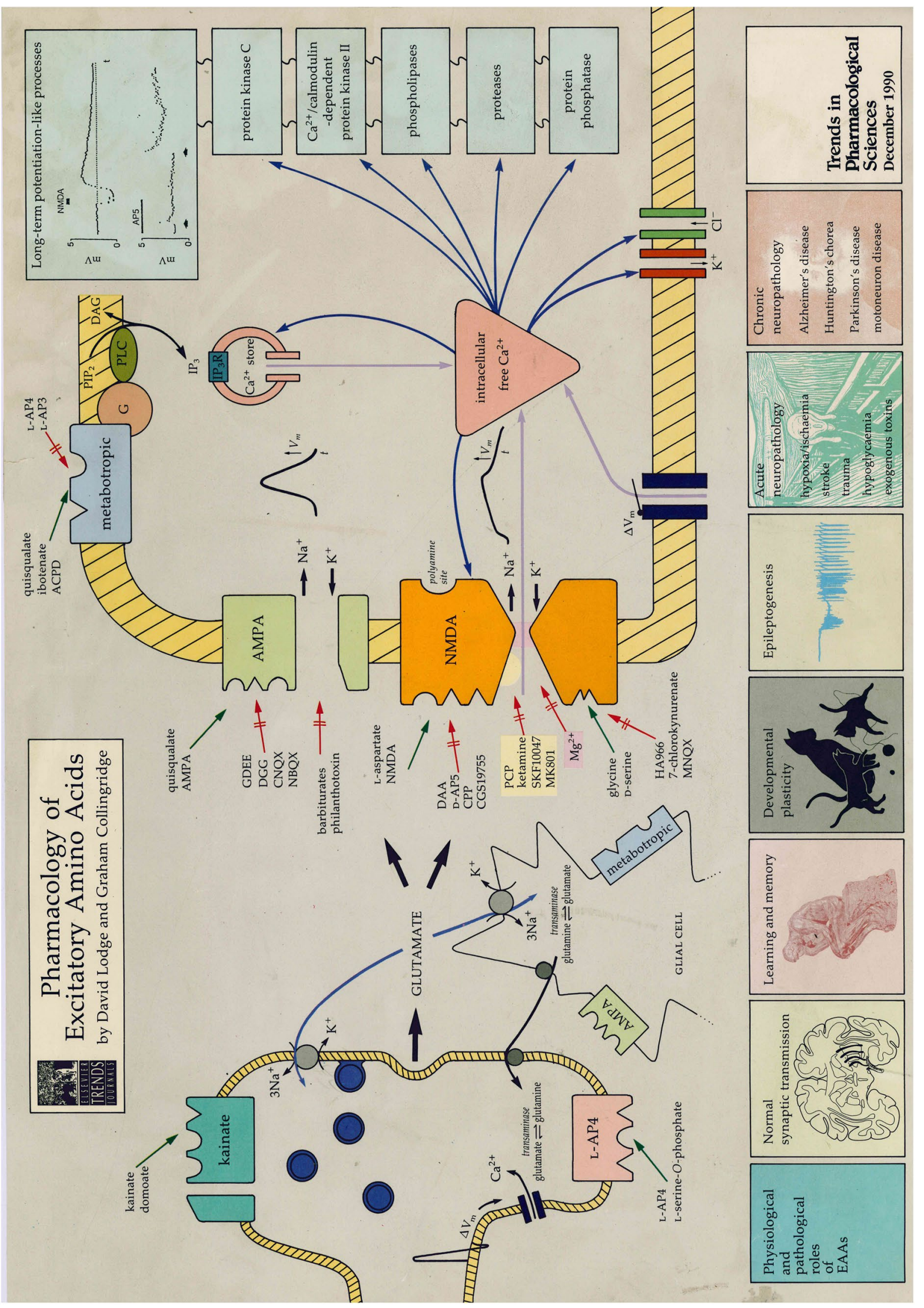


4Fig. 3 Pharmacology of excitatory amino acids: 1991 Poster. This accompanying Poster summarised what had been published in the Special Report. Much of what was simplistically sketched in 1991 still holds true today in 2018 with major advances that have been made in many areas. In particular our knowledge about glutamate receptor involvement in disease has shown huge advances together with advances in the molecular biology, crystal structure, genetics and intracellular signalling of glutamate receptors. Absence of metabotropic glutamate receptors on the illustrated glutamatergic terminal and of pharmacological tools for these G-protein coupled receptors are obvious omissions. Two areas of neuropsychiatry, namely schizophrenia and depression, are now widely linked with NMDA receptor function

\section{Heterogeneity Within NMDA Receptors}

Also in the 1980s, the possibility of subtypes of the NMDA receptor was first raised. Differential sensitivity of brain regions to quinolinic acid, a weak naturally occurring NMDA receptor agonist [210-212] suggested $\mathrm{NMDA}_{1}$ and $\mathrm{NMDA}_{2}$ receptor subtypes. Similarly, regional differences in the sensitivity to glycine and to a variety of NMDA receptor antagonists [213] and to differential stimulation of $\left[{ }^{3} \mathrm{H}\right]$ MK-801 binding by L-glutamate in different brain regions $[214,215]$ and relative affinity of various competitive antagonists in autoradiography studies $[216,217]$ reinforced the idea of heterogeneity in NMDA receptor subtypes. Specific profiles were noted between the rat medial thalamus, the forebrain and the cerebellum [218].

Such suggestions pre-dated the cloning of NMDA receptor subunits in the early 1990 s, which confirmed this heterogeneity. The first cloned subunit [219] is now called GluN1 and is the glycine-sensitive subunit. Cloning of the four glutamate-sensitive subunits, GluN2A-D followed soon [220] and of two more glycine-sensitive GluN3 subunits followed later (reviewed in [221]). Defining the roles of the NMDA receptor subunits in aspects of plasticity has become a major interest of Collingridge and many others [57, 222-230].

\section{Conclusions}

The growing evidence of the role of glutamate and of NMDA receptors in particular, in synaptic transmission received a considerable boost in the 1980s. This was largely driven by the discovery of the highly selective NMDA receptor antagonist, D-AP5, which enabled its use to establish a role for NMDA receptors in synaptic transmission and plasticity $[1,30]$. This review has focussed on some examples of the resulting explosion in knowledge, which were more thoroughly described in a 1991 Supplement of Trends in Pharmacological Sciences, which also included a poster depicting pharmacological tools that were available for targeting of glutamate receptors, synaptic transmission and plasticity Figs. 2, 3.
Acknowledgements Supported by The Royal Society (RSG R1\180384) and the MRC (MR/K023098/1).

\section{Compliance with Ethical Standards}

Conflict of interest The authors have no competing interests to declare.

Open Access This article is distributed under the terms of the Creative Commons Attribution 4.0 International License (http://creativeco mmons.org/licenses/by/4.0/), which permits unrestricted use, distribution, and reproduction in any medium, provided you give appropriate credit to the original author(s) and the source, provide a link to the Creative Commons license, and indicate if changes were made.

\section{References}

1. Collingridge GL, Kehl SJ, McLennan H (1983) Excitatory amino acids in synaptic transmission in the Schaffer collateral-commissural pathway of the rat hippocampus. J Physiol 334:33-46

2. Hebb DO (1949) The organization of behavior: a neuropsychological theory. Wiley, New York

3. Andersen P (1960) Interhippocampal impulses. III. Basal dendritic activation of CA3 neurons. Acta Physiol Scand 48:209230. https://doi.org/10.1111/j.1748-1716.1960.tb01857.x

4. Lømo T (1966) Frequency potentiation of excitatory synaptic activity in the dentate area of the hippocampal formation. Acta Physiol Scand 68(Suppl. 277):128

5. Kandel ER, Spencer WA (1968) Cellular neurophysiological approaches in the study of learning. Physiol Rev 48:65-134

6. Bliss TV, Lomo T (1973) Long-lasting potentiation of synaptic transmission in the dentate area of the anaesthetized rabbit following stimulation of the perforant path. J Physiol 232:331-356

7. Skrede KK, Westgaard RH (1971) The transverse hippocampal slice: a well-defined cortical structure maintained in vitro. Brain Res 35:589-593

8. Schwartzkroin PA, Wester K (1975) Long-lasting facilitation of a synaptic potential following tetanization in the in vitro hippocampal slice. Brain Res 89:107-119

9. Andersen P, Sundberg SH, Sveen O, Wigström H (1977) Specific long-lasting potentiation of synaptic transmission in hippocampal slices. Nature 266:736-737

10. Dunwiddie T, Madison D, Lynch G (1978) Synaptic transmission is required for initiation of long-term potentiation. Brain Res 150:413-417

11. McNaughton BL, Douglas RM, Goddard GV (1978) Synaptic enhancement in fascia dentata: cooperativity among coactive afferents. Brain Res 157:277-293

12. Dunwiddie T, Lynch G (1978) Long-term potentiation and depression of synaptic responses in rat hippocampus-localization and frequency dependency. J Physiol 276:353-367

13. Lynch GS, Dunwiddie T, Gribkoff V (1977) Heterosynaptic depression: a postsynaptic correlate of long-term potentiation. Nature 266:737-739

14. Watkins JC, Jane DE (2006) The glutamate story. Br J Pharmacol 147(Suppl 1):S100-S108. https://doi.org/10.1038/sj.bjp.0706444

15. Lodge D (2009) The history of the pharmacology and cloning of ionotropic glutamate receptors and the development of idiosyncratic nomenclature. Neuropharmacology 56:6-21. https:// doi.org/10.1016/j.neuropharm.2008.08.006

16. Curtis DR, Watkins JC (1961) Analogues of glutamic and gamma-amino-n-butyric acids having potent actions on mammalian neurones. Nature 191:1010-1011 
17. Curtis DR, Watkins JC (1963) Acidic amino acids with strong excitatory actions on mammalian neurones. J Physiol 166:1-14. https://doi.org/10.1113/jphysiol.1963.sp007087

18. McLennan H, Huffman RD, Marshall KC (1968) Patterns of excitation of thalamic neurones by amino-acids and by acetylcholine. Nature 219:387-388

19. Duggan AW (1974) The differential sensitivity to L-glutamate and L-aspartate of spinal interneurones and Renshaw cells. Exp Brain Res 19:522-528

20. McCulloch RM, Johnston GA, Game CJ, Curtis DR (1974) The differential sensitivity of spinal interneurones and Renshaw cells to Kainate and $N$-methyl-D-aspartate. Exp Brain Res 21:515-518

21. Evans RH, Francis AA, Watkins JC (1977) Selective antagonism by $\mathrm{Mg} 2+$ of amino acid-induced depolarization of spinal neurones. Experientia 33:489-491

22. Biscoe TJ, Evans RH, Francis AA et al (1977) D-alpha-Aminoadipate as a selective antagonist of amino acid-induced and synaptic excitation of mammalian spinal neurones. Nature 270:743-745

23. Biscoe TJ, Davies J, Dray A et al (1977) Depression of synaptic excitation and of amino acid induced excitatory responses of spinal neurones by D-alpha-aminoadipate, alpha, epsilon-diaminopimelic acid and HA-966. Eur J Pharmacol 45:315-316

24. Lodge D, Headley PM, Curtis DR (1978) Selective antagonism by D-alpha-aminoadipate of amino acid and synaptic excitation of cat spinal neurons. Brain Res 152:603-608

25. Collingridge GL, Davies J (1979) An evaluation of D-alphaaminoadipate and D-(and DL-)alpha-aminosuberate as selective antagonists of excitatory amino acids in the substantia nigra and mesencephalic reticular formation of the rat. Neuropharmacology 18:193-199

26. McLennan H, Lodge D (1979) The antagonism of amino acidinduced excitation of spinal neurones in the cat. Brain Res 169:83-90

27. Krogsgaard-Larsen P, Honoré T, Hansen JJ et al (1980) New class of glutamate agonist structurally related to ibotenic acid. Nature 284:64-66

28. Watkins JC, Evans RH (1981) Excitatory amino acid transmitters. Annu Rev Pharmacol Toxicol 21:165-204. https://doi. org/10.1146/annurev.pa.21.040181.001121

29. Johnston GA (1976) Glutamate and aspartate as transmitters in the spinal cord. Adv Biochem Psychopharmacol 15:175-184

30. Davies J, Francis AA, Jones AW, Watkins JC (1981) 2-Amino5-phosphonovalerate (2APV), a potent and selective antagonist of amino acid-induced and synaptic excitation. Neurosci Lett 21:77-81

31. Collingridge GL, Kehl SJ, McLennan H (1983) The antagonism of amino acid-induced excitations of rat hippocampal CA1 neurones in vitro. J Physiol 334:19-31

32. Harris EW, Ganong AH, Cotman CW (1984) Long-term potentiation in the hippocampus involves activation of $N$-methyl-Daspartate receptors. Brain Res 323:132-137

33. Wigström H, Gustafsson B (1984) A possible correlate of the postsynaptic condition for long-lasting potentiation in the guinea pig hippocampus in vitro. Neurosci Lett 44:327-332

34. Larson J, Lynch G (1988) Role of $N$-methyl-D-aspartate receptors in the induction of synaptic potentiation by burst stimulation patterned after the hippocampal theta-rhythm. Brain Res 441:111-118

35. Nicoll RA, Kauer JA, Malenka RC (1988) The current excitement in long-term potentiation. Neuron 1:97-103

36. Morris RG, Anderson E, Lynch GS, Baudry M (1986) Selective impairment of learning and blockade of long-term potentiation by an $N$-methyl-D-aspartate receptor antagonist, AP5. Nature 319:774-776. https://doi.org/10.1038/319774a0
37. Errington ML, Lynch MA, Bliss TV (1987) Long-term potentiation in the dentate gyrus: induction and increased glutamate release are blocked by $\mathrm{D}(-)$ aminophosphonovalerate. Neuroscience 20:279-284

38. Harris EW, Cotman CW (1986) Long-term potentiation of guinea pig mossy fiber responses is not blocked by $N$-methyl D-aspartate antagonists. Neurosci Lett 70:132-137

39. Artola A, Singer W (1987) Long-term potentiation and NMDA receptors in rat visual cortex. Nature 330:649-652. https://doi. org/10.1038/330649a0

40. Kleinschmidt A, Bear MF, Singer W (1987) Blockade of "NMDA" receptors disrupts experience-dependent plasticity of kitten striate cortex. Science 238:355-358

41. Gu QA, Bear MF, Singer W (1989) Blockade of NMDAreceptors prevents ocularity changes in kitten visual cortex after reversed monocular deprivation. Brain Res Dev Brain Res 47:281-288

42. McCabe BJ, Horn G (1988) Learning and memory: regional changes in $N$-methyl-D-aspartate receptors in the chick brain after imprinting. Proc Natl Acad Sci USA 85:2849-2853

43. McCabe BJ, Davey JE, Horn G (1992) Impairment of learning by localized injection of an $\mathrm{N}$-methyl-D-aspartate receptor antagonist into the hyperstriatum ventrale of the domestic chick. Behav Neurosci 106:947-953

44. Cline HT, Debski EA, Constantine-Paton M (1987) N-methyl-Daspartate receptor antagonist desegregates eye-specific stripes. Proc Natl Acad Sci USA 84:4342-4345

45. Scherer WJ, Udin SB (1989) N-Methyl-D-aspartate antagonists prevent interaction of binocular maps in Xenopus tectum. J Neurosci 9:3837-3843

46. Schmidt JT (1990) Long-term potentiation and activity-dependent retinotopic sharpening in the regenerating retinotectal projection of goldfish: common sensitive period and sensitivity to NMDA blockers. J Neurosci 10:233-246

47. Pearce IA, Cambray-Deakin MA, Burgoyne RD (1987) Glutamate acting on NMDA receptors stimulates neurite outgrowth from cerebellar granule cells. FEBS Lett 223:143-147

48. Balázs R, Jørgensen OS, Hack N (1988) N-Methyl-D-aspartate promotes the survival of cerebellar granule cells in culture. Neuroscience 27:437-451

49. Singer W (1995) Development and plasticity of cortical processing architectures. Science 270:758-764

50. Collingridge GL, Kehl SJ, Loo R, McLennan H (1983) Effects of kainic and other amino acids on synaptic excitation in rat hippocampal slices: 1. Extracellular analysis. Exp Brain Res 52:170-178

51. Lee HK, Kameyama K, Huganir RL, Bear MF (1998) NMDA induces long-term synaptic depression and dephosphorylation of the GluR1 subunit of AMPA receptors in hippocampus. Neuron 21:1151-1162

52. Coan EJ, Irving AJ, Collingridge GL (1989) Low-frequency activation of the NMDA receptor system can prevent the induction of LTP. Neurosci Lett 105:205-210

53. Dudek SM, Bear MF (1992) Homosynaptic long-term depression in area CA1 of hippocampus and effects of $N$-methyl-D-aspartate receptor blockade. Proc Natl Acad Sci USA 89:4363-4367

54. Mulkey RM, Malenka RC (1992) Mechanisms underlying induction of homosynaptic long-term depression in area CA1 of the hippocampus. Neuron 9:967-975

55. McNaughton BL (1982) Long-term synaptic enhancement and short-term potentiation in rat fascia dentata act through different mechanisms. J Physiol 324:249-262

56. Kauer JA, Malenka RC, Nicoll RA (1988) NMDA application potentiates synaptic transmission in the hippocampus. Nature 334:250-252. https://doi.org/10.1038/334250a0 
57. Volianskis A, Bannister N, Collett VJ et al (2013) Different NMDA receptor subtypes mediate induction of long-term potentiation and two forms of short-term potentiation at CA1 synapses in rat hippocampus in vitro. J Physiol 591:955-972. https://doi. org/10.1113/jphysiol.2012.247296

58. Volianskis A, France G, Jensen MS et al (2015) Long-term potentiation and the role of $N$-methyl-D-aspartate receptors. Brain Res 1621:5-16. https://doi.org/10.1016/j.brainres.2015.01.016

59. Thibault O, Joly M, Muller D et al (1989) Long-lasting physiological effects of bath applied $N$-methyl-D-aspartate. Brain Res 476:170-173

60. MacDonald JF, Wojtowicz JM (1980) Two conductance mechanisms activated by applications of L-glutamic, L-aspartic, DLhomocysteic, $N$-methyl-D-aspartic, and DL-kainic acids to cultured mammalian central neurones. Can J Physiol Pharmacol 58:1393-1397

61. Nowak L, Bregestovski P, Ascher P et al (1984) Magnesium gates glutamate-activated channels in mouse central neurones. Nature 307:462-465

62. Mayer ML, Westbrook GL, Guthrie PB (1984) Voltage-dependent block by $\mathrm{Mg} 2+$ of NMDA responses in spinal cord neurones. Nature 309:261-263

63. Coan EJ, Collingridge GL (1985) Magnesium ions block an $N$-methyl-D-aspartate receptor-mediated component of synaptic transmission in rat hippocampus. Neurosci Lett 53:21-26

64. Blake JF, Brown MW, Collingridge GL (1988) CNQX blocks acidic amino acid induced depolarizations and synaptic components mediated by non-NMDA receptors in rat hippocampal slices. Neurosci Lett 89:182-186

65. Blake JF, Yates RG, Brown MW, Collingridge GL (1989) 6-Cyano-7-nitroquinoxaline-2,3-dione as an excitatory amino acid antagonist in area CA1 of rat hippocampus. Br J Pharmacol 97:71-76

66. Davies SN, Collingridge GL (1989) Role of excitatory amino acid receptors in synaptic transmission in area CA1 of rat hippocampus. Proc R Soc Lond B Biol Sci 236:373-384

67. Andreasen M, Lambert JD, Jensen MS (1989) Effects of new non- $N$-methyl-D-aspartate antagonists on synaptic transmission in the in vitro rat hippocampus. J Physiol 414:317-336

68. Collingridge GL, Herron CE, Lester RA (1988) Synaptic activation of $N$-methyl-D-aspartate receptors in the Schaffer collateral-commissural pathway of rat hippocampus. J Physiol 399:283-300

69. Collingridge GL, Herron CE, Lester RA (1988) Frequencydependent $N$-methyl-D-aspartate receptor-mediated synaptic transmission in rat hippocampus. J Physiol 399:301-312

70. Herron CE, Lester RA, Coan EJ, Collingridge GL (1986) Frequency-dependent involvement of NMDA receptors in the hippocampus: a novel synaptic mechanism. Nature 322:265-268. https://doi.org/10.1038/322265a0

71. MacDermott AB, Mayer ML, Westbrook GL et al (1986) NMDAreceptor activation increases cytoplasmic calcium concentration in cultured spinal cord neurones. Nature 321:519-522. https:// doi.org/10.1038/321519a0

72. Alford S, Frenguelli BG, Schofield JG, Collingridge GL (1993) Characterization of $\mathrm{Ca} 2+$ signals induced in hippocampal CA1 neurones by the synaptic activation of NMDA receptors. J Physiol 469:693-716

73. Dunwiddie TV, Lynch G (1979) The relationship between extracellular calcium concentrations and the induction of hippocampal long-term potentiation. Brain Res 169:103-110

74. Lynch G, Larson J, Kelso S et al (1983) Intracellular injections of EGTA block induction of hippocampal long-term potentiation. Nature 305:719-721

75. Baudry M, Lynch G (1979) Regulation of glutamate receptors by cations. Nature $282: 748-750$
76. Kauer JA, Malenka RC, Nicoll RA (1988) A persistent postsynaptic modification mediates long-term potentiation in the hippocampus. Neuron 1:911-917

77. Muller D, Joly M, Lynch G (1988) Contributions of quisqualate and NMDA receptors to the induction and expression of LTP. Science 242:1694-1697

78. Davies SN, Lester RA, Reymann KG, Collingridge GL (1989) Temporally distinct pre- and post-synaptic mechanisms maintain long-term potentiation. Nature 338:500-503. https://doi. org/10.1038/338500a0

79. Finn RC, Browning M, Lynch G (1980) Trifluoperazine inhibits hippocampal long-term potentiation and the phosphorylation of a 40,000 Dalton protein. Neurosci Lett 19:103-108

80. Lovinger DM, Wong KL, Murakami K, Routtenberg A (1987) Protein kinase $\mathrm{C}$ inhibitors eliminate hippocampal long-term potentiation. Brain Res 436:177-183

81. Reymann KG, Brödemann R, Kase H, Matthies H (1988) Inhibitors of calmodulin and protein kinase $\mathrm{C}$ block different phases of hippocampal long-term potentiation. Brain Res 461:388-392

82. Malinow R, Madison DV, Tsien RW (1988) Persistent protein kinase activity underlying long-term potentiation. Nature 335:820-824. https://doi.org/10.1038/335820a0

83. Lisman JE (1985) A mechanism for memory storage insensitive to molecular turnover: a bistable autophosphorylating kinase. Proc Natl Acad Sci USA 82:3055-3057

84. Miller SG, Kennedy MB (1986) Regulation of brain type II $\mathrm{Ca} 2+/$ calmodulin-dependent protein kinase by autophosphorylation: a Ca2+-triggered molecular switch. Cell 44:861-870

85. Frey U, Krug M, Reymann KG, Matthies H (1988) Anisomycin, an inhibitor of protein synthesis, blocks late phases of LTP phenomena in the hippocampal CA1 region in vitro. Brain Res 452:57-65

86. Frey U, Krug M, Brödemann R et al (1989) Long-term potentiation induced in dendrites separated from rat's CA1 pyramidal somata does not establish a late phase. Neurosci Lett 97:135-139

87. Lynch G, Baudry M (1984) The biochemistry of memory: a new and specific hypothesis. Science 224:1057-1063

88. Linden DJ, Routtenberg A (1989) The role of protein kinase-C in long-term potentiation - a testable model. Brain Res Brain Res Rev 14:279-296

89. Malinow R, Malenka RC (2002) AMPA receptor trafficking and synaptic plasticity. Annu Rev Neurosci 25:103-126. https://doi. org/10.1146/annurev.neuro.25.112701.142758

90. Park P, Volianskis A, Sanderson TM et al (2014) NMDA receptor-dependent long-term potentiation comprises a family of temporally overlapping forms of synaptic plasticity that are induced by different patterns of stimulation. Philos Trans R Soc Lond B Biol Sci 369:20130131-20130131. https://doi.org/10.1098/ rstb.2013.0131

91. Sacktor TC, Hell JW (2017) The genetics of PKM zeta and memory maintenance. Sci Signal. https://doi.org/10.1126/scisi gnal.aao2327

92. Collingridge GL, Bliss TVP (1987) NMDA receptors - their role in long-term potentiation. Trends Neurosci 10:288-293. https:// doi.org/10.1016/0166-2236(87)90175-5

93. Bliss TV, Collingridge GL (1993) A synaptic model of memory: long-term potentiation in the hippocampus. Nature 361:31-39. https://doi.org/10.1038/361031a0

94. Bliss TVP, Collingridge GL (2013) Expression of NMDA receptor-dependent LTP in the hippocampus: bridging the divide. Mol Brain 6:5. https://doi.org/10.1186/1756-6606-6-5

95. Dingledine R, Hynes MA, King GL (1986) Involvement of $\mathrm{N}$-methyl-D-aspartate receptors in epileptiform bursting in the rat hippocampal slice. J Physiol 380:175-189 
96. Wigström H, Gustafsson B (1983) Facilitated induction of hippocampal long-lasting potentiation during blockade of inhibition. Nature 301:603-604

97. Wigström H, Gustafsson B (1983) Large long-lasting potentiation in the dentate gyrus in vitro during blockade of inhibition. Brain Res 275:153-158

98. Davies CH, Davies SN, Collingridge GL (1990) Paired-pulse depression of monosynaptic GABA-mediated inhibitory postsynaptic responses in rat hippocampus. J Physiol 424:513-531

99. Larson J, Wong D, Lynch G (1986) Patterned stimulation at the theta frequency is optimal for the induction of hippocampal longterm potentiation. Brain Res 368:347-350

100. Larson J, Lynch G (1986) Induction of synaptic potentiation in hippocampus by patterned stimulation involves two events. Science 232:985-988

101. Muller D, Lynch G (1988) N-Methyl-D-aspartate receptor-mediated component of synaptic responses to single-pulse stimulation in rat hippocampal slices. Synapse 2:666-668. https://doi. org/10.1002/syn.890020614

102. Wigström H, Gustafsson B (1985) Facilitation of hippocampal long-lasting potentiation by GABA antagonists. Acta Physiol Scand 125:159-172. https://doi.org/10.1111/j.1748-1716.1985. tb07703.x

103. Gustafsson B, Wigström H, Abraham WC, Huang YY (1987) Long-term potentiation in the hippocampus using depolarizing current pulses as the conditioning stimulus to single volley synaptic potentials. J Neurosci 7:774-780

104. Abraham WC, Gustafsson B, Wigström H (1986) Single high strength afferent volleys can produce long-term potentiation in the hippocampus in vitro. Neurosci Lett 70:217-222

105. Huang YY, Wigström H, Gustafsson B (1987) Facilitated induction of hippocampal long-term potentiation in slices perfused with low concentrations of magnesium. Neuroscience 22:9-16

106. Peet MJ, Leah JD, Curtis DR (1983) Antagonists of synaptic and amino acid excitation of neurones in the cat spinal cord. Brain Res 266:83-95

107. Dickenson AH, Sullivan AF (1987) Evidence for a role of the NMDA receptor in the frequency dependent potentiation of deep rat dorsal horn nociceptive neurones following $\mathrm{C}$ fibre stimulation. Neuropharmacology 26:1235-1238

108. Davies SN, Lodge D (1987) Evidence for involvement of $N$-methylaspartate receptors in "wind-up" of class 2 neurones in the dorsal horn of the rat. Brain Res 424:402-406

109. Dawbarn D, Pycock CJ (1981) Motor effects following application of putative excitatory amino acid antagonists to the region of the mesencephalic dopamine cell bodies in the rat. Naunyn Schmiedebergs Arch Pharmacol 318:100-104

110. Crunelli V, Forda S, Kelly JS (1983) Blockade of amino acidinduced depolarizations and inhibition of excitatory post-synaptic potentials in rat dentate gyrus. J Physiol 341:627-640

111. Brown DA, Docherty RJ, Halliwell JV (1983) Chemical transmission in the rat interpeduncular nucleus in vitro. J Physiol 341:655-670. https://doi.org/10.1111/(ISSN)1469-7793

112. Kimura H, Okamoto K, Sakai Y (1985) Pharmacological evidence for L-aspartate as the neurotransmitter of cerebellar climbing fibres in the guinea-pig. J Physiol 365:103-119. https://doi. org/10.1111/(ISSN)1469-7793

113. Fox K, Armstrong-James M (1986) The role of the anterior intralaminar nuclei and $N$-methyl D-aspartate receptors in the generation of spontaneous bursts in rat neocortical neurones. Exp Brain Res 63:505-518

114. Davies J, Miller AJ, Sheardown MJ (1986) Amino acid receptor mediated excitatory synaptic transmission in the cat red nucleus. J Physiol 376:13-29. https://doi.org/10.1111/(ISSN)1469-7793
115. Salt TE (1987) Excitatory amino acid receptors and synaptic transmission in the rat ventrobasal thalamus. J Physiol 391:499-510. https://doi.org/10.1111/(ISSN)1469-7793

116. Mo N, Dun NJ (1987) Excitatory postsynaptic potentials in neonatal rat sympathetic preganglionic neurons: possible mediation by NMDA receptors. Neurosci Lett 77:327-332

117. Davies J, Evans RH, Jones AW et al (1982) Differential activation and blockade of excitatory amino acid receptors in the mammalian and amphibian central nervous systems. Comp Biochem Physiol C Comp Pharmacol 72:211-224

118. Dale N, Roberts A (1985) Dual-component amino-acid-mediated synaptic potentials: excitatory drive for swimming in Xenopus embryos. J Physiol 363:35-59

119. Corradetti R, King AE, Nistri A et al (1985) Pharmacological characterization of D-aminophosphonovaleric acid antagonism of amino acid and synaptically evoked excitations on frog motoneurones in vitro: an intracellular study. Br J Pharmacol 86:19-25. https://doi.org/10.1111/(ISSN)1476-5381

120. Brodin L, Grillner S, Rovainen CM (1985) N-Methyl-D-aspartate (NMDA), kainate and quisqualate receptors and the generation of fictive locomotion in the lamprey spinal cord. Brain Res 325:302-306

121. Dale N, Grillner S (1986) Dual-component synaptic potentials in the lamprey mediated by excitatory amino acid receptors. J Neurosci 6:2653-2661

122. Lukasiewicz PD, McReynolds JS (1985) Synaptic transmission at $N$-methyl-D-aspartate receptors in the proximal retina of the mudpuppy. J Physiol 367:99-115

123. Massey SC, Miller RF (1990) N-Methyl-D-aspartate receptors of ganglion cells in rabbit retina. J Neurophysiol 63:16-30. https://doi.org/10.1152/jn.1990.63.1.16

124. Garthwaite J (1985) Cellular uptake disguises action of L-glutamate on $N$-methyl-D-aspartate receptors. With an appendix: diffusion of transported amino acids into brain slices. Br J Pharmacol 85:297-307. https://doi.org/10.1111/(ISSN)1476-5381

125. Olverman HJ, Jones AW, Watkins JC (1984) L-glutamate has higher affinity than other amino acids for [3H]-D-AP5 binding sites in rat brain membranes. Nature 307:460-462

126. Monaghan DT, Yao D, Olverman HJ et al (1984) Autoradiography of D-2-[3H]amino-5-phosphonopentanoate binding sites in rat brain. Neurosci Lett 52:253-258

127. Baudry M (1986) Long-term potentiation and kindling: similar biochemical mechanisms? Adv Neurol 44:401-410

128. Cain DP (1989) Long-term potentiation and kindling: how similar are the mechanisms? Trends Neurosci 12:6-10

129. Slater NT, Stelzer A, Galvan M (1985) Kindling-like stimulus patterns induce epileptiform discharges in the guinea pig in vitro hippocampus. Neurosci Lett 60:25-31

130. Mody I, Heinemann U (1987) NMDA receptors of dentate gyrus granule cells participate in synaptic transmission following kindling. Nature 326:701-704. https://doi.org/10.1038/326701a0

131. Coutinho-Netto J, Abdul-Ghani AS, Collins JF, Bradford HF (1981) Is glutamate a trigger factor in epileptic hyperactivity? Epilepsia 22:289-296

132. Croucher MJ, Collins JF, Meldrum BS (1982) Anticonvulsant action of excitatory amino acid antagonists. Science 216:899-901

133. Meldrum BS, Croucher MJ, Badman G, Collins JF (1983) Antiepileptic action of excitatory amino acid antagonists in the photosensitive baboon, Papio papio. Neurosci Lett 39:101-104

134. Herron CE, Williamson R, Collingridge GL (1985) A selective $\mathrm{N}$-methyl-D-aspartate antagonist depresses epileptiform activity in rat hippocampal slices. Neurosci Lett 61:255-260

135. Anderson WW, Swartzwelder HS, Wilson WA (1987) The NMDA receptor antagonist 2-amino-5-phosphonovalerate blocks stimulus train-induced epileptogenesis but not epileptiform 
bursting in the rat hippocampal slice. J Neurophysiol 57:1-21. https://doi.org/10.1152/jn.1987.57.1.1

136. Stelzer A, Slater NT, Bruggencate ten G (1987) Activation of NMDA receptors blocks GABAergic inhibition in an in vitro model of epilepsy. Nature 326:698-701. https://doi. org/10.1038/326698a0

137. Kleckner NW, Dingledine R (1989) Selectivity of quinoxalines and kynurenines as antagonists of the glycine site on $N$-methylD-aspartate receptors. Mol Pharmacol 36:430-436

138. Horne AL, Harrison NL, Turner JP, Simmonds MA (1986) Spontaneous paroxysmal activity induced by zero magnesium and bicuculline: suppression by NMDA antagonists and GABA mimetics. Eur J Pharmacol 122:231-238

139. Aram JA, Lodge D (1987) Epileptiform activity induced by alkalosis in rat neocortical slices: block by antagonists of $N$-methylD-aspartate. Neurosci Lett 83:345-350

140. Ashwood TJ, Wheal HV (1986) Extracellular studies on the role of $N$-methyl-D-aspartate receptors in epileptiform activity recorded from the kainic acid-lesioned hippocampus. Neurosci Lett 67:147-152

141. Avoli M, Olivier A (1987) Bursting in human epileptogenic neocortex is depressed by an $N$-methyl-D-aspartate antagonist. Neurosci Lett 76:249-254

142. Armstrong-James M, Fox K (1988) Evidence for a specific role for cortical NMDA receptors in slow-wave sleep. Brain Res 451:189-196

143. Aanonsen LM, Wilcox GL (1987) Nociceptive action of excitatory amino acids in the mouse: effects of spinally administered opioids, phencyclidine and sigma agonists. J Pharmacol Exp Ther 243:9-19

144. Cahusac PM, Evans RH, Hill RG et al (1984) The behavioural effects of an $N$-methylaspartate receptor antagonist following application to the lumbar spinal cord of conscious rats. Neuropharmacology 23:719-724

145. Haley JE, Sullivan AF, Dickenson AH (1990) Evidence for spinal $\mathrm{N}$-methyl-D-aspartate receptor involvement in prolonged chemical nociception in the rat. Brain Res 518:218-226

146. Mendell LM (1984) Modifiability of spinal synapses. Physiol Rev 64:260-324. https://doi.org/10.1152/physrev.1984.64.1.260

147. Thompson SW, King AE, Woolf CJ (1990) Activity-dependent changes in rat ventral horn neurons in vitro; summation of prolonged afferent evoked postsynaptic depolarizations produce a d-2-amino-5-phosphonovaleric acid sensitive windup. Eur $\mathbf{J}$ Neurosci 2:638-649

148. Coderre TJ, Melzack R (1991) Central neural mediators of secondary hyperalgesia following heat injury in rats: neuropeptides and excitatory amino acids. Neurosci Lett 131:71-74

149. Barnes CA (1988) Aging and the physiology of spatial memory. Neurobiol Aging 9:563-568. https://doi.org/10.1016/S0197 $-4580(88) 80114-3$

150. Morris RG (1989) Synaptic plasticity and learning: selective impairment of learning rats and blockade of long-term potentiation in vivo by the $N$-methyl-D-aspartate receptor antagonist AP5. J Neurosci 9:3040-3057

151. McNaughton BL, Morris RGM (1987) Hippocampal synaptic enhancement and information storage within a distributed memory system. Trends Neurosci 10:408-415. https://doi. org/10.1016/0166-2236(87)90011-7

152. Danysz W, Wroblewski JT, Costa E (1988) Learning impairment in rats by $N$-methyl-D-aspartate receptor antagonists. Neuropharmacology 27:653-656

153. Tonkiss J, Morris RG, Rawlins JN (1988) Intra-ventricular infusion of the NMDA antagonist AP5 impairs performance on a non-spatial operant DRL task in the rat. Exp Brain Res 73:181-188
154. Staubli U, Thibault O, DiLorenzo M, Lynch G (1989) Antagonism of NMDA receptors impairs acquisition but not retention of olfactory memory. Behav Neurosci 103:54-60

155. Olney JW, Labruyere J, Collins JF, Curry K (1981) D-aminophosphonovalerate is 100 -fold more powerful than D-alphaaminoadipate in blocking $N$-methylaspartate neurotoxicity. Brain Res 221:207-210

156. Garthwaite G, Hajós F, Garthwaite J (1986) Ionic requirements for neurotoxic effects of excitatory amino acid analogues in rat cerebellar slices. Neuroscience 18:437-447

157. Meldrum B, Garthwaite J (1990) Excitatory amino acid neurotoxicity and neurodegenerative disease. Trends Pharmacol Sci 11:379-387

158. Scharfman HE, Schwartzkroin PA (1989) Protection of dentate hilar cells from prolonged stimulation by intracellular calcium chelation. Science 246:257-260

159. Watson GB, Rader RK, Lanthorn TH (1989) Epileptiform activity in vitro can produce long-term synaptic failure and persistent neuronal depolarization. Brain Res 498:81-88

160. Furshpan EJ, Potter DD (1989) Seizure-like activity and cellular damage in rat hippocampal neurons in cell culture. Neuron 3:199-207

161. Benveniste H, Drejer J, Schousboe A, Diemer NH (1984) Elevation of the extracellular concentrations of glutamate and aspartate in rat hippocampus during transient cerebral ischemia monitored by intracerebral microdialysis. J Neurochem 43:1369-1374

162. Hagberg H, Lehmann A, Sandberg $M$ et al (1985) Ischemiainduced shift of inhibitory and excitatory amino acids from intra- to extracellular compartments. J Cereb Blood Flow Metab 5:413-419. https://doi.org/10.1038/jcbfm.1985.56

163. Engelsen B, Westerberg E, Fonnum F, Wieloch T (1986) Effect of insulin-induced hypoglycemia on the concentrations of glutamate and related amino acids and energy metabolites in the intact and decorticated rat neostriatum. J Neurochem 47:1634-1641

164. Simon RP, Swan JH, Griffiths T, Meldrum BS (1984) Blockade of $N$-methyl-D-aspartate receptors may protect against ischemic damage in the brain. Science 226:850-852

165. Wieloch T (1985) Hypoglycemia-induced neuronal damage prevented by an $N$-methyl-D-aspartate antagonist. Science 230:681-683

166. Collins RC, Dobkin BH, Choi DW (1989) Selective vulnerability of the brain: new insights into the pathophysiology of stroke. Ann Intern Med 110:992-1000

167. Watkins JC (1962) The synthesis of some acidic amino acids possessing neuropharmacological activity. J Med Pharm Chem 91:1187-1199

168. Lunn WH, Schoepp DD, Calligaro DO et al (1992) DL-tetrazol5-ylglycine, a highly potent NMDA agonist: its synthesis and NMDA receptor efficacy. J Med Chem 35:4608-4612

169. Allan RD, Hanrahan JR, Hambley TW et al (1990) Synthesis and activity of a potent $N$-methyl-D-aspartic acid agonist, trans1-aminocyclobutane-1,3-dicarboxylic acid, and related phosphonic and carboxylic acids. J Med Chem 33:2905-2915

170. Lanthorn TH, Hood WF, Watson GB et al (1990) Cis-2,4-methanoglutamate is a potent and selective $N$-methyl-D-aspartate receptor agonist. Eur J Pharmacol 182:397-404

171. Shinozaki H, Ishida M, Shimamoto K, Ohfune Y (1989) Potent NMDA-like actions and potentiation of glutamate responses by conformational variants of a glutamate analogue in the rat spinal cord. Br J Pharmacol 98:1213-1224. https://doi.org/10.1111/ (ISSN)1476-5381

172. Monahan JB, Hood WF, Compton RP et al (1990) Characterization of D-3,4-cyclopropylglutamates as $N$-methyl-D-aspartate receptor agonists. Neurosci Lett 112:328-332 
173. Kawai M, Horikawa Y, Ishihara T et al (1992) 2-(Carboxycyclopropyl)glycines: binding, neurotoxicity and induction of intracellular free Ca2+ increase. Eur J Pharmacol 211:195-202

174. Jane DE, Olverman HJ, Watkins JC (1994) Agonists and competitive antagonists: structure-activity and molecular modelling studies. In: Collingridge GL, Watkins JC (eds) The NMDA receptor, 2nd edn. Oxford University Press, Oxford, pp 31-104

175. Fagg GE, Olpe HR, Pozza MF et al (1990) CGP 37849 and CGP 39551: novel and potent competitive $N$-methyl-D-aspartate receptor antagonists with oral activity. Br J Pharmacol 99:791797. https://doi.org/10.1111/(ISSN)1476-5381

176. Lehmann J, Hutchison AJ, McPherson SE et al (1988) CGS 19755, a selective and competitive $N$-methyl-D-aspartate-type excitatory amino acid receptor antagonist. J Pharmacol Exp Ther 246:65-75

177. Evans RH, Francis AA, Jones AW et al (1982) The effects of a series of omega-phosphonic alpha-carboxylic amino acids on electrically evoked and excitant amino acid-induced responses in isolated spinal cord preparations. Br J Pharmacol 75:65-75

178. Perkins MN, Stone TW, Collins JF, Curry K (1981) Phosphonate analogues of carboxylic acids as aminoacid antagonists on rat cortical neurones. Neurosci Lett 23:333-336

179. Davies J, Evans RH, Herrling PL et al (1986) CPP, a new potent and selective NMDA antagonist. Depression of central neuron responses, affinity for [3H]D-AP5 binding sites on brain membranes and anticonvulsant activity. Brain Res 382:169-173

180. Harris EW, Ganong AH, Monaghan DT et al (1986) Action of 3-((+/-)-2-carboxypiperazin-4-yl)-propyl-1-phosphonic acid (CPP): a new and highly potent antagonist of $N$-methyl-D-aspartate receptors in the hippocampus. Brain Res 382:174-177

181. Aebischer B, Frey P, Haerter H-P et al (1989) Synthesis and NMD A antagonistic properties of the enantiomers of 4-(3-phosphonopropyl)piperazine-2-carboxylic acid (CPP) and of the unsaturated analogue (E)-4-(3-phosphonoprop-2-enyl)piperazine-2-carboxylic acid (CPP-ene). Helv Chim Acta 72:10431051. https://doi.org/10.1002/hlca.19890720522

182. Ornstein PL, Klimkowski VJ (1992) Competitive NMDA receptor antagonists. In: Krogsgaard-Larsen P, Hansen JJ (eds) Excitatory amino acid receptors. Design of agonists and antagonists. Ellis Horwood Ltd, Chichester, pp 183-201

183. Müller W, Lowe DA, Neijt H et al (2004) Synthesis and $N$-Methyl-D-aspartate (NMDA) antagonist properties of the enantiomers of $\alpha$-amino-5-(phosphonomethyl)[1,1'-biphenyl]3 -propanoic acid. Use of a new chiral glycine derivative. Helv Chim Acta 75:855-864. https://doi.org/10.1002/hlca.19920 750320

184. Olverman HJ, Monaghan DT, Cotman CW, Watkins JC (1986) $[3 \mathrm{H}] \mathrm{CPP}$, a new competitive ligand for NMDA receptors. Eur $\mathbf{J}$ Pharmacol 131:161-162

185. Murphy DE, Hutchison AJ, Hurt SD et al (1988) Characterization of the binding of [3H]-CGS 19755: a novel $N$-methyl-D-aspartate antagonist with nanomolar affinity in rat brain. Br J Pharmacol 95:932-938. https://doi.org/10.1111/(ISSN)1476-5381

186. Sills MA, Fagg G, Pozza M et al (1991) [3H]CGP 39653: a new $\mathrm{N}$-methyl-D-aspartate antagonist radioligand with low nanomolar affinity in rat brain. Eur J Pharmacol 192:19-24

187. Fagg GE, Matus A (1984) Selective association of $N$-methyl aspartate and quisqualate types of L-glutamate receptor with brain postsynaptic densities. Proc Natl Acad Sci USA 81:6876-6880

188. Monaghan DT, Cotman CW (1986) Identification and properties of $N$-methyl-D-aspartate receptors in rat brain synaptic plasma membranes. Proc Natl Acad Sci USA 83:7532-7536

189. Wong EH, Knight AR, Ransom R (1987) Glycine modulates [3H]MK-801 binding to the NMDA receptor in rat brain. Eur $\mathbf{J}$ Pharmacol 142:487-488
190. Herrling PL (1997) Excitatory amino acids: clinical results with antagonists. Academic, London

191. Muir KW (2006) Glutamate-based therapeutic approaches: clinical trials with NMDA antagonists. Curr Opin Pharmacol 6:53-60. https://doi.org/10.1016/j.coph.2005.12.002

192. Stringer JL, Guyenet PG (1983) Elimination of long-term potentiation in the hippocampus by phencyclidine and ketamine. Brain Res 258:159-164

193. Stringer JL, Greenfield LJ, Hackett JT, Guyenet PG (1983) Blockade of long-term potentiation by phencyclidine and sigma opiates in the hippocampus in vivo and in vitro. Brain Res 280:127-138

194. Lodge D, Anis NA (1982) Effects of phencyclidine on excitatory amino acid activation of spinal interneurones in the cat. Eur $\mathbf{J}$ Pharmacol 77:203-204

195. Anis NA, Berry SC, Burton NR, Lodge D (1983) The dissociative anaesthetics, ketamine and phencyclidine, selectively reduce excitation of central mammalian neurones by $\mathrm{N}$-methylaspartate. Br J Pharmacol 79:565-575. https://doi.org/10.1111/ (ISSN)1476-5381

196. Berry SC, Dawkins SL, Lodge D (1984) Comparison of sigmaand kappa-opiate receptor ligands as excitatory amino acid antagonists. Br J Pharmacol 83:179-185. https://doi.org/10.1111/ (ISSN) 1476-5381

197. MacDonald JF, Miljkovic Z, Pennefather P (1987) Use-dependent block of excitatory amino acid currents in cultured neurons by ketamine. J Neurophysiol 58:251-266. https://doi.org/10.1152/ jn.1987.58.2.251

198. Lodge D, Mercier MS (2015) Ketamine and phencyclidine: the good, the bad and the unexpected. Br J Pharmacol 172:42544276. https://doi.org/10.1111/bph.13222

199. White PF, Way WL, Trevor AJ (1982) Ketamine-its pharmacology and therapeutic uses. Anesthesiology 56:119-136

200. Thomson AM, West DC, Lodge D (1985) An N-methylaspartate receptor-mediated synapse in rat cerebral cortex: a site of action of ketamine? Nature 313:479-481

201. Aram JA, Martin D, Tomczyk M et al (1989) Neocortical epileptogenesis in vitro: studies with $N$-methyl-D-aspartate, phencyclidine, sigma and dextromethorphan receptor ligands. J Pharmacol Exp Ther 248:320-328

202. Chapman AG, Meldrum BS (1989) Non-competitive $N$-methylD-aspartate antagonists protect against sound-induced seizures in DBA/2 mice. Eur J Pharmacol 166:201-211

203. Rauschecker JP, Hahn S (1987) Ketamine-xylazine anaesthesia blocks consolidation of ocular dominance changes in kitten visual cortex. Nature 326:183-185. https://doi.org/10.1038/32618 $3 \mathrm{a} 0$

204. Johnson JW, Ascher P (1987) Glycine potentiates the NMDA response in cultured mouse brain neurons. Nature 325:529-531. https://doi.org/10.1038/325529a0

205. Fletcher EJ, Lodge D (1988) Glycine reverses antagonism of $\mathrm{N}$-methyl-D-aspartate (NMDA) by 1-hydroxy-3-aminopyrrolidone-2 (HA-966) but not by D-2-amino-5-phosphonovalerate (D-AP5) on rat cortical slices. Eur J Pharmacol 151:161-162

206. Foster AC, Kemp JA (1989) HA-966 antagonizes $N$-methyl-Daspartate receptors through a selective interaction with the glycine modulatory site. J Neurosci 9:2191-2196

207. Kemp JA, Foster AC, Leeson PD et al (1988) 7-Chlorokynurenic acid is a selective antagonist at the glycine modulatory site of the $N$-methyl-D-aspartate receptor complex. Proc Natl Acad Sci USA 85:6547-6550

208. Kessler M, Terramani T, Lynch G, Baudry M (1989) A glycine site associated with $N$-methyl-D-aspartic acid receptors: characterization and identification of a new class of antagonists. J Neurochem 52:1319-1328 
209. Ingram R, Kang H, Lightman S et al (2018) Some distorted thoughts about ketamine as a psychedelic and a novel hypothesis based on NMDA receptor-mediated synaptic plasticity. Neuropharmacology. https://doi.org/10.1016/j.neuropharm.2018.06.008

210. Perkins MN, Stone TW (1983) Quinolinic acid: regional variations in neuronal sensitivity. Brain Res 259:172-176

211. Lehmann J, Schaefer P, Ferkany JW, Coyle JT (1983) Quinolinic acid evokes $[3 \mathrm{H}]$ acetylcholine release in striatal slices: mediation by NMDA-type excitatory amino acid receptors. Eur J Pharmacol 96:111-115

212. Monaghan DT, Beaton JA (1991) Quinolinate differentiates between forebrain and cerebellar NMDA receptors. Eur J Pharmacol 194:123-125

213. Monaghan DT, Olverman HJ, Nguyen L et al (1988) Two classes of $N$-methyl-D-aspartate recognition sites: differential distribution and differential regulation by glycine. Proc Natl Acad Sci USA 85:9836-9840

214. Monaghan DT (1991) Differential stimulation of [3H]MK-801 binding to subpopulations of NMDA receptors. Neurosci Lett 122:21-24

215. Reynolds IJ, Palmer AM (1991) Regional variations in [3H] MK801 binding to rat brain $N$-methyl-D-aspartate receptors. J Neurochem 56:1731-1740

216. O'Shea RD, Manallack DT, Conway EL et al (1991) Evidence for heterogenous glycine domains but conserved multiple states of the excitatory amino acid recognition site of the NMDA receptor: regional binding studies with $[3 \mathrm{H}]$ glycine and $[3 \mathrm{H}]$ L-glutamate. Exp Brain Res 86:652-662

217. Beaton JA, Stemsrud K, Monaghan DT (1992) Identification of a novel $N$-methyl-D-aspartate receptor population in the rat medial thalamus. J Neurochem 59:754-757

218. Buller AL, Larson HC, Schneider BE et al (1994) The molecular basis of NMDA receptor subtypes: native receptor diversity is predicted by subunit composition. J Neurosci 14:5471-5484

219. Moriyoshi K, Masu M, Ishii T et al (1991) Molecular cloning and characterization of the rat NMDA receptor. Nature 354:31-37. https://doi.org/10.1038/354031a0

220. Monyer H, Seeburg PH (1993) Constituents involved in glutamate receptor signaling. Hippocampus 3:125-129

221. Pachernegg S, Strutz-Seebohm N, Hollmann M (2012) GluN3 subunit-containing NMDA receptors: not just one-trick ponies.
Trends Neurosci 35:240-249. https://doi.org/10.1016/j. tins.2011.11.010

222. Hrabetova S, Sacktor TC (1997) Long-term potentiation and long-term depression are induced through pharmacologically distinct NMDA receptors. Neurosci Lett 226:107-110

223. Hrabetova S, Serrano P, Blace N et al (2000) Distinct NMDA receptor subpopulations contribute to long-term potentiation and long-term depression induction. J Neurosci 20:RC81

224. Liu L, Wong TP, Pozza MF et al (2004) Role of NMDA receptor subtypes in governing the direction of hippocampal synaptic plasticity. Science 304:1021-1024. https://doi.org/10.1126/ science. 1096615

225. Massey PV, Johnson BE, Moult PR et al (2004) Differential roles of NR2A and NR2B-containing NMDA receptors in cortical long-term potentiation and long-term depression. J Neurosci 24:7821-7828. https://doi.org/10.1523/JNEUR OSCI.1697-04.2004

226. Berberich S, Punnakkal P, Jensen V et al (2005) Lack of NMDA receptor subtype selectivity for hippocampal longterm potentiation. J Neurosci 25:6907-6910. https://doi. org/10.1523/JNEUROSCI.1905-05.2005

227. Bartlett TE, Bannister NJ, Collett VJ et al (2007) Differential roles of NR2A and NR2B-containing NMDA receptors in LTP and LTD in the CA1 region of two-week old rat hippocampus. Neuropharmacology 52:60-70. https://doi.org/10.1016/j.neuro pharm.2006.07.013

228. Morishita W, Malenka RC (2008) Mechanisms underlying dedepression of synaptic NMDA receptors in the hippocampus. J Neurophysiol 99:254-263. https://doi.org/10.1152/jn.01011 .2007

229. Bartlett TE, Lu J, Wang YT (2011) Slice orientation and muscarinic acetylcholine receptor activation determine the involvement of $N$-methyl D-aspartate receptor subunit GluN2B in hippocampal area CA1 long-term depression. Mol Brain 4:41. https ://doi.org/10.1186/1756-6606-4-41

230. France G, Fernández-Fernández D, Burnell ES et al (2017) Multiple roles of GluN2B-containing NMDA receptors in synaptic plasticity in juvenile hippocampus. Neuropharmacology 112:76-83. https://doi.org/10.1016/j.neuropharm.2016.08.010 